Kong. Res. J. 4(2): 47-51, 2017

ISSN 2349-2694

Kongunadu Arts and Science College, Coimbatore.

\title{
CONSERVATION OF SACRED GROVES, CULTURAL CONNECTIONS AND CONTROLLING CLIMATE CHANGE
}

\author{
Ramanujam. M.P. \\ Botany Laboratory, KM Centre for Post Graduate Studies, Lawspet, Puducherry - 605 008, India. \\ E.mail: mpraman@gmail.com
}

\begin{abstract}
Sacred groves signify the practice of conserving biodiversity with strong beliefs, customs and taboos and are treasure house of rare and endemic species. Everything within these groves is under the protection of the reigning deity of the grove and the removal of any material, even dead wood or twig is a taboo (Gadgil and Vartak, 1976). Such groves still exist in many parts of the world and represent relict vegetation of the locality, preserved in its original form with minimal disturbance. Preservation of these groves, though on the pretext of religious beliefs, is of importance for conserving germ plasm that is otherwise under threat from human interference (Khiewtan and Ramakrishnan, 1989). Among the sacred groves along the coastal sector centering Pondicherry $(90 \mathrm{~km} \times 50 \mathrm{~km})$ on the east coast of India, Puthupet (28ha), Senthirankillai (15ha), Thoppaiyankulam (10.5ha), Kotthatai (6.15ha) and Karukkai (5.2ha.) were larger groves, the smaller being Sedrapet, Ramanathapuram and Kumalam, each measuring ca.0.2 ha. Of late, ecologists evince interest in the potential of biodiversity in carbon -' $\mathrm{C}$ ' sequestration and storage. In some selected groves, the biosequestered atmospheric carbon (C) values ranged from 47.7 to $120.5 \mathrm{Mg} \mathrm{ha}^{-1}$. The quantum of C-storage in a sacred grove, however small it may be, and its implied role in mitigating the climate change, is now confirmed. These groves which have rich, varied and valuable biodiversity conserved in them can also contribute to tackling climate change, which is another most serious environmental problem facing the humankind.
\end{abstract}

Keywords: Sacred groves, climate change, environmental problem.

\section{INTRODUCTION}

Nature has always been very vibrant, giving and resilient to a very large extent. One of the critical issues on the national and global agenda is the need to preserve biodiversity for future generations while trying to understand and document the indigenous knowledge of resource management practices. Religion, being a powerful instrument for convincing people, has always been used for meeting the desired objectives of the society

Most religions project the worship of sun, wind, land, trees, plants, and water which is the very base of human survival. Snake worship prevailed in ancient India from time immemorial. Garuda, lion, peacock, crow, cow, mouse, elephant and tiger are part of our cultural ethos emphasizing the conservation of wildlife. Almost the entire living of God Ram and Goddess Sita was very close to nature. The very concept of Sthala vriksha is aimed at arresting the decline of important plant specieds in the wild. The sangam literature depicts that the ancient Tamils evolved every aspect of their life in relation to nature. Some prominent live examples of traditional and cultural forms of biodiversity conservation still exist and are in practice, which include sacred groves, sacred species and sacred landscapes.
The concept of scared groves as instrument of biodiversity conservation was evolved by the ancient people. These have survived through the millennia mainly because of the belief system associated with them. Everything within these groves is under the protection of the reigning deity of the grove and the removal of any material, even dead wood or twig is a taboo (Gadgil and Vartak, 1976). Such groves still exist in many parts of the world and represent relict vegetation of the locality, preserved in its original form with minimal disturbance. Preservation of these groves, though on the pretext of religious beliefs, is of importance for conserving germplasm that is otherwise under threat from human interference (Khiewtan and Ramakrishnan, 1989).

In India, they occur in Western Ghats, Madhya Pradesh, Maharashtra, Meghalaya, Karnataka, etc., and found in variety of habitats from scrub forests of Thar Desert (maintained by Bishnois), to rain forests of Kerala in Western Ghats, Himachal Pradesh in the North and Kerala in the south are specifically known for their large number of sacred groves.

Gadgil and Vartak $(1975,1976)$ initiated the study in India when they enlisted hundreds of groves on the Western Ghats of Karnataka and Maharashtra 
regions. Subsequently, groves were discovered from all over India and several new features were found to be associated with them. Groves in the leeward side of Aravalli regions were sparsely wooded patches dominated by Vanni (Prosopis cineraria) trees; those on the North Eastern Himalayan ranges were evergreen or deciduous formation; most of the groves in the plains were mono or multi-species the clusters; some were relicts of past vegetations bearing testimony to the chequered course of ecological history. Nevertheless, despite the divergence on their type and physiognomy, they shared certain common features like having a dense or sparse cover of tress, presence of a village deity in iconic or uniconic form, a routine form worship along with an annual festival, restrictions on the use of natural resources from the groves, taboos and folklores tailored to regulate human behavior and strategic association with a perennial water source.

As more information flowed in, the concept of the sacred groves have also been widened to include any patch of trees, natural or anthropogenic, that is dedicated to a village God and has constrained resource use pattern woven into the tapestry of cultural traditions (Somasheker 1999).

In several regions, the groves are islets of natural vegetation surrounded by either agricultural fields or denuded forest ranges. Interestingly, many of them contained rare and endangered taxa that are seldom found elsewhere. The protection ensured by the cultural traditions and religious sanctions over the millennia, has allowed the plants to grow into tall and robust tress or giant lianas. Hence, they may be a museum of giant specimens, recreation centres and spiritual retreats, refugia of relicts and endemic taxa, laboratories for environmentalists, sanctuaries for birds and fauna, dispensaries of medicinal plants, gene bank of economic species, water-sheds which recharge of aquifers. In fact, certain well preserved groves are even equated to minibiosphere reserves.

Interestingly some are mono-dominant groves. The choice of species for raising such groves is also socially significant. The geo-climatic considerations coupled to the variety and intensity of utility of the tree for local people have influenced the selection.. Whereas the Bamboo of Sal or teak trees constituted the stands in the hill tracts, Tamarind, Punnai, Ilppai, Panai have been dominating the rural landscapes in the plains.

The UNESCO-WWF sponsored nationwide survey led by Prof. Ramarakrishnan of Jawaharlal Nehru University, New Delhi has documented the existence of groves from all parts of India
(Ramakrishnan et al., 1998) Still, Tamil Nadu's contribution to this compilation is meagre and minimal. It is not that the Tamil-speaking areas were bereft of the groves, as the recent initiatives have proved (Amirthalingam, 2014).

For Tamil Nadu - Pondicherry region, Meher - Homji (1986) from the French Institute, Pondicherry first reported a patch of tropical Dry Evergreen Forest (TDEF) dedicated to Lord Manjiny and Airyanar which was protected a strong religious belief system and cultural traditions. Occupying over 20 ha, it harboured 104 plant species belonging to 44 Angionsperm families. It is a relict patch of erstwhile tropical dry evergreen vegetation (Champion and Seth, 1968).

Amirthalingam (1998) C.P. Ramasawmy iyer foundation of Chennai (CPRF) has undertaken the stupendous task of survey and restoration of Tamilnadu groves and enlisted 82 groves with appreciable floristic value from the Districts of Pudhukottai and Tiruchirappalli. Subsequently, CPRF has surveyed and resurrected several denuded groves and successfully restored several them to their original status in Tamilnadu and Andhra Pradesh (Nanditha and Javanthi, 1997; Amirthalingam, 1998). Nenmeli grove near Chengalpattu is a classic example of restoration wherein the stake-holders displayed a keen interest.

Parthasarathy's group from Pondicherry University studied the phytosociology of three groves in Pondicherry - Cuddalore region and declared these are essentially TDFF patches viz. Thirumanikkuzhi, Puthupet, Kulandhaikuppam. (Parthasarathy and Karthikeyan, 1997; Parathasarathy and Sethi, 1997). King (1997) found a grove at Suriyampet, near Cuddalore which could also be considered a relict of TDFF. Swamy et al. (1998) from Madurai Kamaraj University, enumerated scores of groves in Madurai, Sivangangai and Kanyakumari districts and noted the aboundance of Artocartpus integribolius and $A$. heterophyllus in the less - disturbed groves. Some of them were $>10$ ha in extent.

The coastal sector covering Pondicherry, Cuddalore and Villupuram districts has been the focus of research by our group. Stretching over 350 Sq. Km, this sector has 180 groves, of which 50 had rich biodiversity values (Kadamban, 1998; Pravenkumar, 1999; Ramanujam et al., 2002; Krishnan, 2004) After Puthupet, Senthirankillai and Thuthipattu measuring $>10.5$ ha each were larger groves; the smallest was Ranganavaram, Ramanathapuram and Kumalam measuring ca.0.2 ha each. 
A major outcome from these diverse initiatives is that there are hundred of groves with biodiversity potential in Tamilnadu especially in PondicherryVillupuram-Cuddalore-Pudhukottai sector. They may be a museum of giant specimens, recreation centres and spiritual retreats, refugia of relicts and endemic taxa, laboratories for environmentalists, sanctuaries for birds and fauna, dispensaries of medicinal plants, gene bank of economic species and watersheds which recharge the aquifers. In fact, certain well preserved groves are even equated to minibiosphere reserves.

However, there are alarming signs of their degradation mainly due to defective management policies. Chandran and Hughes (1997) reviewing the status of sacred groves attributed the ascendance of religious/cultural considerations over conservation ethos, spread and establishment of monotheistic religions, influence of western culture and modernism which shifted the primacy from biodiversity to temple construction and worship pattern and conversion of forests to agriculture or plantations. It is imperative that the conservation strategy is reoriented to revive them since they contain significant biodiversity and botanical values.

The concept of sacred grove was not a component of protected Area Network (PAN). Nevertheless, their biodiversity potential is immense and needs to be preserved on a priority basis. The earth summit of 1992 that adopted the "Convention of Biodiversity" (CBD) provided the necessary impetus to the sacred grove initiatives. The Forest Department of Govt. of Puducherry has proposed to declare them as 'Community Reserves" under Wildlife Protection Act of 1972. Realising the value of the rich flora and fauna a contained within the groves, Alternatively, they can be declared as "Biodiversity Heritage Sites" (BHS) under the Biodiversity Act 2002. The National Biodiversity Authority has framed rules facilating their new status as BHS.

\section{TASKS REMAINING}

Nevertheless, certain grey areas remain. Their role in nutrient enrichment, soil preservation and moderation of microclimate is yet to be substantiated in different climatic zones. Though most are associated with water bodies, the watershed management value is unclear. More important is the livelihood support documented in hill regions but not in the plains. As they have more shrubs and trees, their capacity to absorb atmospheric Carbon and thereby reducing the C-impact on climate change is almost untouched. Ecologists have started evincing interest in the potential functional relationship between biodiversity and carbon-'C' sequestration and storage (Kirby and Potvin, 2007). Forests sequester and store more $C$ than any other territorial ecosystem and are an important 'brake' on climate change (Gibbs et al., 2007).

In this background, an attempt was made to assess the potential of such groves in sequestering atmospheric carbon which is the major contributing factor to global warming. While the preservation of groves will conserve local biodiversity, it will indirectly mitigate the climate change through enhanced carbon capture. That is a major aspect of clean development mechanism (CDM).

To fill this void, the woody plant diversity, phytosociology and conservation of seven coastal and three interior groves in Cuddalore district of Tamil Nadu was taken up by Praveenkumar (2011) recently. The ten groves are: Aiyanar grove at Sedapalayam Pudhur (SP), Kasambu Nayagi grove at Chinnakumatti (CK), Chetty Veerappaswamy Grove at Kothattai (KT), Ponni Amman grove at Indiranagar (PK), Pacahaivazhi Amman grove at Palvalthunnan (PT), Muni Aiyanar and Nallanayagi grove at Senthirankillai (SK), Aiyanar grove at Anayankuppam (BM), Kurumbaiyanar grove at Karukkai (KK), Aiyanar grove at Elavathadi (EL) and Muthu Muneeswaran grove at Thoppayankulam (TP).

Together they occupy 38.11 ha. While SP (10.06 ha), KT (5.32ha) and SK (3.04 ha) are larger groves exceeding 10 acres, EL (1.2 ha), BM (0.7 ha) are smaller. The species richness ranges from 13 $(\mathrm{BM})$ to 37 (SK). A total of 80 Woody species, including 62 species of trees and 18 species of lianas have been enumerated from the ten groves. They are distributed in 64 genera belonging to 39 families. Of the constituent species, evergreens dominated the coastal groves. In KK deciduous elements take over (394 individuals belonging to 10 species). Familywise, Rubiaceae with six genera is the most represented family followed by Rutaceae with five genera, Euphorbiaceae and Fabaceae-Faboideae with three and Fabaceae-Caesalpinioideae with two genera.

The above ground biomass (AGB) has been calculated by Praveenkumr to understand the growth status of forest stand (Murali et al., 2005). The above ground biomass (AGB) values of the ten sites ranged between $130 \mathrm{Mg}$ ha to 219.7, averaging 163.6. As the AGB is an extrapolation of BA, the tree architecture and height contribute to the estimations immensely. These values were also used for calculating the carbon stock values, as adopted by Gairola et al. (2011). As recommended by IPCC, 0.47 
of the AGB is taken as carbon percentage since broad leaved species and deciduous species constituted the vegetation in the study sites; it is 0.26 for root system (Mc Groddy et al., 2004) It is represented as total carbon density TCD ( $\mathrm{Mg} \mathrm{C}$ ha $\left.^{-1}\right)$.

\section{MODERATION OF MICROCLIMATE}

The air temperature was invariably less by $1-3^{\circ} \mathrm{C}$ inside the groves compared to the open surroundings. In TP, SK, PT and SP, where the canopy was thick and continuous, it was cooler by 2 $3^{\circ} \mathrm{C}$ but differed by just $1^{\circ} \mathrm{C}$ in the dry tracts of $\mathrm{BM}$ and PK. The temperature inside the grove despite the nature of the canopy always remained lower than outside. While it is tempting to downplay the impact on microclimate as shade effect, the cool and comfort provided by the trees is really enjoyable.
This is in line with the observations of Jaryan et al. (2009) who for the first time assessed the microclimate in Shivbari grove in Himachal Pradesh.

\section{CARBON STOCKING}

The total carbon sequestered by the sacred grove sites, taken as a 0.47 fraction for aerial parts and 0.26 fraction of the root system as recommended by IPCC (Mc Groddy et al., 2004), Wherever the proportion of crooked stems and stunted trees was high or the shrub layer is dense, the biomass values have decreased correspondingly. The carbon stock values varied between 47.7 to $120.5 \mathrm{Mg} \mathrm{ha}^{-1)}$. Only well grown forests of Garhwal Himalaya have a the total carbon ( TCD) stock of 178.4 $\mathrm{Mg} \mathrm{ha}^{-1}$ (Gairola et al., 2011).

Table 1. Carbon stocking of the 10 sacred groves in Cuddalore district of Tamilnadu.

\begin{tabular}{llllllllllll}
\hline $\begin{array}{l}\text { S. } \\
\text { no }\end{array}$ & \multicolumn{1}{c}{ Grove } & SP & CK & KT & PK & PT & SK & BM & KK & EL & TP \\
\hline 1 & $\begin{array}{l}\text { Biomass } \\
\text { (AGB) (Mg ha-1) }\end{array}$ & 101.6 & 157.9 & 146.9 & 135.1 & 205.3 & 219.7 & 256.5 & 196.8 & 170.2 & 172.7 \\
2 & $\begin{array}{l}\text { Carbon stock- ACD } \\
\text { (Mg C ha-1) }\end{array}$ & 47.7 & 74.2 & 69.1 & 63.5 & 96.3 & 103.3 & 120.5 & 92.5 & 79.8 & 81.2 \\
3 & $\begin{array}{l}\text { Carbon stock- } \\
\text { BCD (Mg C ha-1) }\end{array}$ & 26.4 & 40.9 & 38.0 & 35.1 & 53.4 & 55.6 & 66.7 & 51.2 & 44.2 & 44.9 \\
4 & $\begin{array}{l}\text { Total Carbon stock- } \\
\text { TCD (Mg C ha-1) }\end{array}$ & 74.1 & 116.7 & 107.1 & 98.6 & 149.7 & 158.9 & 187.2 & 143.7 & 124.0 & 126.9 \\
\hline
\end{tabular}

(Calculated On The Basis Of Above Ground Biomass Values as recommended by inter governmental panel on climate change - IPCC ) (Mg

$=$ Metagram $=10-15$

The maximum biomass and carbon have been stocked in SK, PT, BM and KK, and minimum in SP. While the high density of stems has contributed to the higher biomass values in $\mathrm{SK}$, fewer but tall and robust trees did it for PT and KK. Though the stem density may be low at EL, the trees are voluminous.

\section{Name of the Grove Village}

Veera Aiyanarappan Thirukkoil Sedapalayam-Pudur

Kasambunayaki (Informal)

Chettiveerappa

Kovil(Informal)

Pachavazhaiamman Kovil

Ponniyamman Kovil

Muniyanar Kovil Thoppu

Aiyanar Kovil

Kurumbu Aiyanar Kovil

Aiyanar Kovil

Munieeswaran Kovil

Accordingly the short statured strands in SP,

$\mathrm{PK}$, and KT scored the lowest values compared to the dense and tall stands of SK, PT and TP.

* Any how, these values tally with the 90.25 to 173.1 range from the coastal sites and 73 to 138.73 for inland sites
In other groves too, the stocked carbon levels are appreciable since the biosequestered atmospheric carbon (C) is uniformly $47 \%$ of the biomass. Despite smaller size of groves and varying $A B G$ values, the contribution of sacred groves to mitigation of global warming is certainly remarkable.

\section{Area(ha.)}

8.2 - low tree cover

2.16 - dense and tall trees

6.2- low tree cover

2.17 -sparse tall trees

1.2- dense and tall trees

3.5- dense and tall trees

1.1 - sparse tree cover

5.1 sparse, tall trees

1.2- sparse tall trees

3.8- dense and tall stands

It also compares favourably with the total Biomass density (TBD) $135.6 \mathrm{Mg} \mathrm{ha}^{-1}$ for an Indian forest estimated in 1993 and AGB range of 171.9 to $380.3 \mathrm{Mg}$ ha $^{-1}$ reestimated in 2011(Gairola et al. 2011). 
Considering that these values are only approximations, the quantum of $\mathrm{C}$-storage in sacred groves, however small it may be, and its implied role in mitigating the climate change, is certainly significant.

\section{CONCLUSIONS}

In conclusion, the carbon capturing potential of the selected sacred groves among the agricultural/urban societies. It confirms that these groves which have the rich, varied and valuable biodiversity conserved in them can also contribute to tackling Climate change, which is another most serious environmental problem we facing the human kind.

It now demands a paradigm shift in the attitude of the public as well as the administrators to acknowledge the tangible and intangible benefits from the groves. With no economic dependence, not even incentives, disinterest of the farming community cannot be faulted upon either. But given their social status and educational background of the elders and the adverse impacts of rationality, urbanization and modernism on the young and middle classes, it seems a distant dream to integrate them into mainstream conservation measures. It is imperative to strengthen the people - grove interface by imprinting the values of ecosystem services in them. Nothing could be more alluring than the earning carbon credits through the Clean Development Mechanism (CDM).

\section{REFERENCES}

Gairola, S., C.M. Sharma, S.K. Ghildiyal and S. Suyal, (2011). Live tree biomass and carbon variation along an altitudinal gradient in moist temperate valley slopes of the Garhwal Himalaya (India). Curr. Sci 100: 19.

Gibbs, H.K., S. Brown, J.O. Nilesand and J.A. Foley, (2007). Monitoring and estimating tropical forest carbon stocks: making REDD a reality. Environ. Res. Lett 2: 1-13.

McGroddy, M.E., T. Daufresne and L.O. Hedin, (2004). Scaling of C:N:P stoichiometry in forests worldwide: implications of terrestrial Redfield-type ratios. Ecology 85: 2390-2401. Praveenkumar, C.K. (2011). Plant Biodiversity and Biocultural Perspectives of Ten Sacred Groves in Cuddalore District of Tamil Nadu, South India, Ph.D. Thesis, Pondicherry University. 